\title{
Impact of the quality of life of inseminators on the results of artificial insemination programs in beef cattle ${ }^{1}$
}

\author{
Lívia dos Santos Russi 2,3, Eliane Vianna da Costa-e-Silva ${ }^{2,4}$, Carmem Estefânia Serra Neto \\ Zúccari $^{2,5}$, Caciliana da Silva Recalde ${ }^{2,6}$, Norly Gomes Cardoso ${ }^{7}$
}

${ }^{1}$ Suporte financeiro: FUNDECT/MS.

2 Grupo de Estudos em Reprodução Animal no Mato Grosso do Sul. GERA-MS/CNPq.

${ }^{3}$ Programa de Pós-Graduação em Ciência Animal - FAMEZ/UFMS. Bolsista CAPES/CNPq.

${ }^{4}$ Departamento de Medicina Veterinária. Faculdade de Medicina Veterinária e Zootecnia - UFMS. Campo Grande, MS.

${ }^{5}$ Departamento de Zootecnia. Faculdade de Medicina Veterinária e Zootecnia - UFMS. Campo Grande, MS.

${ }^{6}$ Bolsista iniciação científica CNPq. Acadêmica de Medicina Veterinária FAMEZ/UFMS.

7 Psicóloga, CRP 01963/4, 14ª região.

\begin{abstract}
The objective of the present study was to evaluate the effect of factors of personal life and work conditions on the results obtained by inseminators in conventional and fixed-timed artificial insemination programs in beef cattle. Inseminators from three farms (21 in the total) were interviewed and evaluated according to the general obtained pregnancy rates. The differences among the pregnancy rates obtained in the farms, motivation and its association with the obtained pregnancy rate and the effect of each variable of the groups of needs on the pregnancy rate at first insemination were evaluated. The open questions were grouped by similarity and then analyzed by frequency of the answers. Pregnancy rates obtained by the inseminators ranged from 12 to $57 \%$, with a mean service index of $3.10 \pm 1.62$ doses/pregnancy. It was also observed that the satisfaction of biological, financial, and training needs was more intimately related to the pregnancy rate than the satisfaction of the other needs, although none had shown an antagonistic relationship with it. Factors concerned to life quality and to the work can be important in determining the performance of these professionals.
\end{abstract}

Key Words: human resources management, job satisfaction

\section{Impacto da qualidade de vida dos inseminadores nos resultados de programas de inseminação artificial em bovinos de corte}

\begin{abstract}
RESUMO - Objetivou-se avaliar o efeito de fatores ligados à vida pessoal e ao trabalho sobre os resultados obtidos por inseminadores em programas de inseminação artificial convencional e em tempo fixo em bovinos de corte. Inseminadores de três propriedades rurais (21 no total) foram entrevistados e avaliados quanto à taxa de gestação geral obtida. Foram avaliadas as diferenças entre as taxas de gestação obtidas nas fazendas, a motivação e sua associação com a taxa de gestação obtida e o efeito de cada variável dos grupos de necessidades sobre a taxa de gestação à primeira inseminação. As questões abertas, depois de agrupadas por similaridade, foram analisadas por frequência de respostas. A taxa de gestação obtida pelos inseminadores variou entre 12 e 57\%, com índice de serviço de 3,10 \pm 1,62 doses/prenhez. A satisfação das necessidades biológicas, financeiras e de treinamento foi mais intimamente relacionada à taxa de gestação que a satisfação das demais necessidades, embora nenhuma delas tenha apresentado relação antagônica com a taxa de gestação. Fatores ligados à qualidade de vida e ao trabalho podem ser importantes na determinação do desempenho dos inseminadores.
\end{abstract}

Palavras-chave: gestão de recursos humanos, satisfação no trabalho

\section{Introduction}

Human resource management has been widely used in many urban companies but this new management vision has been little applied in the rural area, so that inseminators are managed empirically, without well-defined criteria.

The lack of guidelines can produce undesirable results, because many factors can impair the performance of these professionals. The level of work satisfaction, for example, has already been quoted as an important factor that influences health and, consequently, productivity (Faragher et al., 2005) and can even damage motivation of the workers, that is directly related to meeting the needs of the individuals.

These needs, according to Maslow's theory, are organized in levels and can be visualized as a pyramid (Maslow, 1970, quoted by Hagerty, 1999). The biological 
needs are followed by personal safety, both of vital importance to man. The social needs are at the third level and include affective aspects and acceptance. Selfrealization is on the top and it includes the way the individual sees himself and his desire for continuous development.

This hierarchical distribution implies that only when a lower need level is met, the immediately higher need arises in the behavior, determining that when more needs are met the individual will become more motivated (Chiavenato, 1999).

The inseminator has a fundamental role in insemination efficiency and for this reason the lack of skills of this professional is a limiting factor in obtaining satisfactory conception results. Several studies have shown its effect on the results of artificial insemination programs in beef cattle (Reurink et al., 1990; Fernandes Jr., 2001; Vendruscolo et al., 2005) but there are few studies that show the effect of factors linked to the quality of life on the performance of these professionals.

Thus, a study was carried out with the objective of assessing the effect of factors linked to personal life and work on the results obtained by inseminators in conventional and fixed-time artificial insemination programs in beef cattle.

\section{Material and Methods}

Twenty-one inseminators from three private farms with extensive beef cattle raising systems were interviewed during the reproductive season from January to March 2007.

Farm A is located in the municipality of Presidente Epitácio, extreme western São Paulo state (latitude $22^{\circ} 01^{\prime} 44^{\prime \prime S}$, longitude $52^{\circ} 14$ ' $41^{\prime \prime} \mathrm{W}$, altitude $300 \mathrm{~m}$ ), with flat topography, mean annual rainfall from 1.300 to $1.400 \mathrm{~mm}$ and $23^{\circ} \mathrm{C}$ mean annual temperature that ranges from $10^{\circ} \mathrm{C}$ to $36^{\circ} \mathrm{C}$ (INPE, 2008). It has pastures composed mainly by Brachiaria brizantha and Panicum maximum. Farms B and $\mathrm{C}$ are located in the Central Western region of Brazil, on the transition between Pantanal and Central Plateau of the state of Mato Grosso do Sul, in the municipality of Miranda.

All of the farms have masonry houses for the married workers and lodgings with collective sanitary installations and dining rooms for the single workers.

The questions applied in the interviews were developed with the help of psychologists and they were tested in a preexperimental phase to verify their efficiency in extracting information that could be used to trace a profile of these professionals. The interviews were individually performed, in a location reserved for this purpose, on each farm, to maintain the secrecy of the obtained information.
Firstly, it was explained the objective of the interview to each participant and after the necessary explanations, each one was instructed to read and fill out a term of consent, elaborated according to the norms of the Committee of Ethics in Human Experimentation of the Universidade Federal do Mato Grosso do Sul, to permit the use of the data resulting from the interviews.

The questions were divided into four large groups. The first, called "personal data”, included questions on gender, age, civil state, number of children, position/function, schooling, satisfaction with housing (yes or no) and desire to carry out alterations on the house (yes or no).

The second group, "social life”, included questions on the possibility of weekend leave (yes or no), type of leisure activities (individual or collective) and religious belief (yes or no). Individual activities were considered to be those that the individual could carry out alone, such as watching television, and collective activities were those the individual would carry out in a group, such as playing football.

The third group, "health", dealt with questions on medical and dental assistance subsidized by the farm, the use of medication, accidents resulting from work with the animals and sleep quality, all with the binomial type of response (yes or no).

The fourth group, “professional”, included questions related to professional experience such as the age at which the individual started working, time of working in the company, satisfaction with the current wages (yes or no), insemination and recycling course (yes or no), type of insemination that they considered the best (conventional or fixed-time), knowledge of rational management and interest in taking new courses (both with binomial response) and plans for the future (individual or collective). For the last variable, individual plans were considered to be those regarding only the individual, such as obtaining a better job, and collective to be those regarding third parties, such as buying a house for the family or ensuring the education of the children.

At the end of the interview stage, the responses were categorized, following the Maslow's need hierarchy model. The level of need satisfaction was assessed according to the percentage of responses labeled as "ideal” for each item of the group of assessed needs, and the level was classified as high (3) $-100 \%$, medium (2) -50 to $75 \%$ or low (1) $-<50 \%$.

Given the binomial nature of most of the considered variables (answer alternatives yes $=1$ or no $=0$ ), the combinations classified as "ideal” are shown below, for the respective needs groups:

- Biological: satisfaction with housing (1), desire to carry out alterations on the house (0) and quality of sleep (1); 
-Personal safety: medical and dental assistance (1), use of medication ( 0 ) and work accidents (0);

-Financial security: satisfaction with wages (1);

-Social: religion (1), marital status (married), weekend leave (1) and leisure activities (collective activities);

-Training: insemination course (1), recycling (1), knowledge of rational management (1), interest in taking new courses (1).

A general classification was determined from these combinations of needs satisfaction corresponding to the obtained modal values, that is, the value of the satisfaction level (high, medium or low) that was the most repeated for each individual, considering all the assessed needs.

This information was analyzed together with the information supplied by the farm on the performance of the inseminator in the reproductive season from November/ 2006 to January/2007, considering the pregnancy rates at first insemination, general pregnancy rate $[P R=$ (total of pregnant females/total inseminated females) x 100] and service index ( $\mathrm{SI}=$ number of doses/pregnancy). The pregnancy rate referred only to the results from insemination, regardless of the number of inseminations and mating with bulls.

For statistical analysis, the analyses of variance were carried out to assess the differences among the pregnancy rates of the farms and the means were compared by the Duncan's test. The association between the level of needs satisfaction and the pregnancy rate was verified with the Spearman correlation and principal component analysis. The chi-square test was used to verify the individual effect of each variable of the groups of needs on the pregnancy rates at the first insemination. The open questions were analyzed by response frequency after being grouped by similarity. All the analyses $(\mathrm{P}<0.05)$ were carried out using the SAS statistical program (SAS, 1999).

\section{Results and Discussion}

The data for the inseminator performance included 2,276 female cattle (Table 1) that received, at the first artificial insemination, fixed-time $(n=1,863)$ or conventional insemination ( $\mathrm{n}=413$ ), with observation of the estrus (only on farm C).

The mean pregnancy rate obtained among the farms was $37.60 \pm 11.59(\mathrm{CV}=30.84)$, the pregnancy rate at the first insemination was $37.51 \pm 11.19(\mathrm{CV}=29.82)$ and the results obtained varied among the farms (Figure 1). The general pregnancy rates obtained by the inseminators ranged from 12 to $57 \%$, with a mean service index of $3.10 \pm 1.62$ doses/ pregnancy. It is pointed out that the cost of semen doses is one of the factors that may affect the cost of implanting artificial insemination and it might damage its economic benefits (Pfeifer et al., 2009).

The interviewees were, on average, $36.62 \pm 10.46$ $(\mathrm{CV}=28.57)$ years old, had $2.05 \pm 1.36(\mathrm{CV}=66.8)$ children, started working at $13.14 \pm 3.68(\mathrm{CV}=27.99)$ years of age and their time of employment in the current company was 10.81 \pm 7.35 (CV $=67.96)$ years. About $90 \%(19 / 21)$ were married, $57 \%(12 / 21)$ said they practiced some religion and $62 \%$ $(13 / 21)$ stated they were satisfied with their living conditions. Regarding their job, 62\% (13/21) performed general services, 28.6\% (6/21) were field hands and 9.5\% (2/21) were foremen.

Most of the interviewees had incomplete primary education and $38 \%(8 / 21)$ of these had not completed the first four grades. Only 14.3\% (3/21) had taken technical courses, which proved that schooling was precarious among these workers, probably because of the difficult access to schools in the rural area and because they began working while they were still very young, which may have contributed to their quitting studies at the initial grades.

On the health assessment, 71\% (15/21) of the workers stated they had medical and dental assistance subsidized by the farm and $29 \%(6 / 21)$ made use of continuous

Table 1 - Distribution of inseminators, bulls and cows submitted to artificial insemination on three farms in the Southeastern and Central Western regions of Brazil

\begin{tabular}{lcccc}
\hline & Farm A & Farm B & Farm C & Total \\
\hline Inseminators & 2 & 6 & 13 & 21 \\
Cows & 118 & 544 & 1,614 & 2,276 \\
\hline
\end{tabular}

Farm A = 3 Bonsmara and 2 Nellore bulls; Farm B = 2 Brangus, 2 Red Angus and 13 Nellore bulls; Farm C $=27$ Nellore bulls.

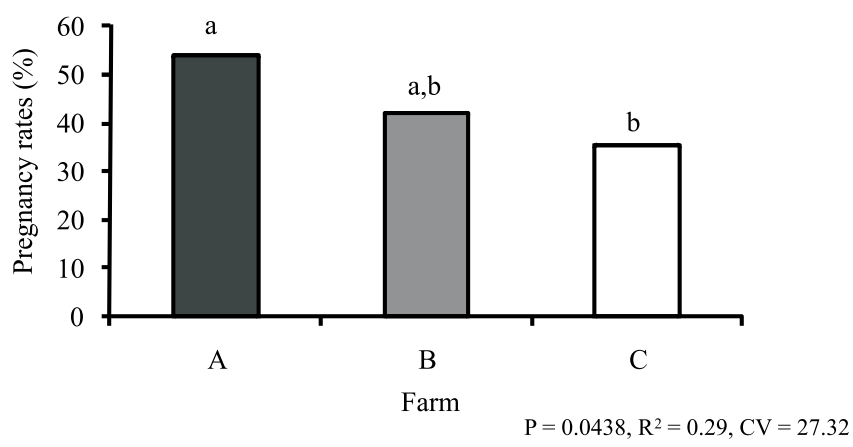

Figure 1 - Pregnancy rates in beef cattle obtained in conventional and/or fixed-time artificial insemination programs on three farms in the Southeastern and Central Western regions of Brazil. Different letters indicate difference $(\mathrm{P}<0.05)$ by the Duncan's test. $\mathrm{CV}=$ coefficient of variance. 
medication. However, 67\% (14/21) stated they had already suffered accidents resulting from managing the animals and $24 \%(5 / 21)$ had undergone surgeries because of these accidents. This is a worrying result that highlights the need for investments in training, especially on rational management techniques. Accidents during management can represent high costs for the farm because they mean the lay-off of the worker for long periods of time; they may also represent more serious consequences for the worker, such as irreparable lesions (Teixeira \& Freitas, 2003).

On the study of the satisfaction of individual needs, significant positive Spearman correlations were found in all the groups of needs, suggesting that the higher the need satisfaction is, the better the inseminator performed (Table 2).

The principal component analysis basically consists on rewriting the coordinates of the samples in another axle system that is more convenient for data analysis, so that the original variables (in the case the groups of needs) are reduced to the principal components obtained in decreasing order of maximum variance. Although the statistical information is the same as the original variables the analysis permits, in practical terms, that most of this information can be obtained with only two or three of the principal components, so that the importance of the original variables chosen can be judged, that is, those that have a greater weight in the combination of the first principal components will be the most important from the statistical point of view (Moita Neto \& Moita, 1998).

The results obtained in the multivariate analysis indicated that the first three principal components explained $83 \%$ of the detected variance (Table 3 ), suggesting that their linear combination may give important explanations as to which needs would be most important in determining the results of the inseminators.

As the values obtained for principal component 1 were all positive, which placed all the variables on the same plane, it was chosen to work with the linear combination between components 2 and 3, which allowed a better assessment of the ratio between the satisfaction level of the individual needs among themselves and between the obtained pregnancy rates (Figure 2).

Satisfaction of the biological, financial and training needs was more closely related to the pregnancy rate than that of the other needs, although none presented an antagonistic relationship with the general pregnancy rates obtained. Antagonism was observed, however, between satisfaction of the social and training needs with the satisfaction of the biological and financial needs.

Table 3 - Eigenvalues of the principal components obtained from the corresponding modal values at the level of need satisfaction of inseminators $(n=21)$ working in the Southeastern and Central Western regions of Brazil

\begin{tabular}{ccccc}
\hline $\begin{array}{l}\text { Principal } \\
\text { Component }\end{array}$ & Eigenvalues & Difference & Proportion & $\begin{array}{c}\text { Cumulative } \\
\text { Variance }\end{array}$ \\
\hline 1 & 3.26 & 2.22 & 0.54 & 0.54 \\
2 & 1.05 & 0.35 & 0.17 & 0.72 \\
3 & 0.70 & 0.21 & 0.12 & 0.83 \\
\hline
\end{tabular}

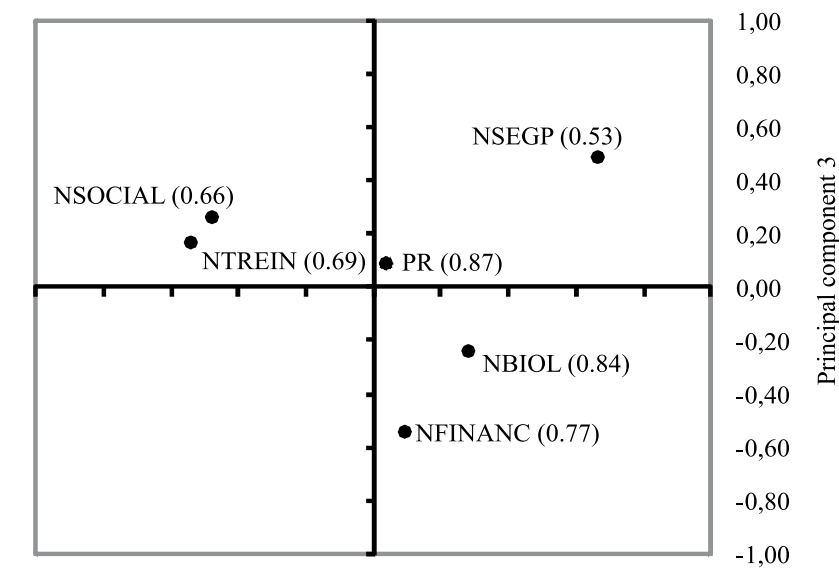

$\begin{array}{lllllllllll}-1,00 & -0,80 & -0,60 & -0,40 & -0,20 & 0,00 & 0,20 & 0,40 & 0,60 & 0,80 & 1,00\end{array}$

Principal component 2

Figure 2 - Level of inseminator $(n=21)$ need satisfaction in the Southeast and Central Western regions of Brazil. NBIOL = biological need, NFINANC = financial security need, NSEGP = personal security need, NSOCIAL = social need, NTREIN = training need, $\mathrm{PR}=$ general pregnancy rate .

Table 2 - Spearman correlation coefficients between the modal values obtained from the satisfaction level of the individual needs of inseminators $(\mathrm{n}=21)$ from three farms in the Southeastern and Central Western regions of Brazil

\begin{tabular}{|c|c|c|c|c|c|c|}
\hline & Biological need & Personal security need & Social need & Financial security need & Training need & General (all needs) \\
\hline Pregnancy rate & $0.60 * *$ & $0.44^{*}$ & $0.43^{*}$ & $0.54 * *$ & $0.53 * *$ & $0.60 * *$ \\
\hline Biological need & 1 & 0.36 & 0.39 & $0.57 * *$ & $0.44^{*}$ & $0.87 * * *$ \\
\hline Personal security need & - & 1 & 0.16 & $0.52 *$ & 0.34 & $0.50 *$ \\
\hline Social need & - & - & 1 & 0.18 & $0.55 * *$ & $0.52 *$ \\
\hline Financial security need & - & - & - & 1 & 0.33 & $0.53 *$ \\
\hline Training need & - & - & - & - & 1 & $0.50 *$ \\
\hline
\end{tabular}

* $\mathrm{P}<0.05 ; * * \mathrm{P}<0.01 ; * * * \mathrm{P}<0.0001$ 
These findings suggested that the more skilled the individual was (most satisfied training needs), the more dissatisfied with his wage and living conditions he would be. Similarly, when he was more satisfied in the social part, he would become more dissatisfied with these same conditions. These associations can be explained by the fact that wages and housing conditions are not always improved with the greater skill of the inseminator. Furthermore, the farm may offer good social support, with leisure opportunities, without modifying those conditions.

In the isolated assessment of the effect of the biological needs, satisfaction with housing did not influence $(\mathrm{P}=0.0619$; $\left.\chi^{2}=3.49\right)$ the pregnancy rate $(40.6 \%$ for the satisfied versus $36.4 \%$ for the dissatisfied), but there was an effect of sleep quality $\left(\mathrm{P}<0.0001 ; \chi^{2}=19.27\right)$ on the pregnancy rate $(39.5 \%$ for those that slept well versus $24.3 \%$ for the others).

These results can be justified by the fact that more than $60 \%$ of the interviewees stated they were satisfied with their housing conditions, which may have decreased the relevance of this variable in determining the results obtained in insemination. Furthermore, the result showed the importance of sleep quality on productivity that can be easily understood when the essential restorative function of sleep is considered in maintaining the balance of the organism (Kapczinski et al., 2000 quoted by Tertuliano, 2003).

In the personal safety need group, differences in the pregnancy rates $(\mathrm{P}<0.05)$ were found only in relation to the use of medication ( $33.6 \%$ yes versus $40.4 \%$ no, $\chi^{2}=9.58$ ) and work accidents ( $36.7 \%$ yes versus $42 \%$ no, $\chi^{2}=4.18$ ), which confirmed the influence of the health state of the worker on his productivity.

Among the social needs, there was a significant difference only for weekend leave ( $40 \%$ yes versus $29.8 \%$ no; $\left.\mathrm{P}=0.001 ; \chi^{2}=15.11\right)$ and leisure activities (48.6\% collective activities versus $35.8 \%$ individual activities; $\mathrm{P}<0.0001 ; \chi^{2}=18.81$ ), which corroborated to the proposals by De Masi (2000), who stated that idleness is necessary for quality of life and for an optimum production because it offers the possibility of satisfying important needs related to introspection and social interaction that have a great weight in the motivation of the worker. Additionally, Michie (2002) stated that among the factors that can help to overcome the pressures of the work environment and to determine greater productivity the most important would be the personal characteristics, such as ability for adaptations and facility in social relationships, in addition to the social support offered by the company.

Among the training needs, only the recycling $\left(\chi^{2}=19.67\right)$ and the insemination courses $\left(\chi^{2}=22.56\right)$ showed difference $(\mathrm{P}<0.0001)$ in the pregnancy rate $(38.9 \%$ versus $14.7 \%$ for those that did or did not take the course, respectively), demonstrating the importance of training on the performance of the inseminator. Confidence on the used insemination technique was also shown to be important, because the inseminator who did not believe in the efficiency of fixed-time artificial insemination obtained lower pregnancy rates than those obtained by the ones who believed in the technique ( $36 \%$ versus $40.4 \%$, respectively; $\mathrm{P}=0.0438$ ).

Recycling is very important for the efficiency of the inseminator, because it makes him more interested in the processes used in insemination and increases his skill and self-confidence (King \& MacPherson, 1965). Peters et al. (1984) showed by X-rays that approximately one-third of the inseminator deposited the semen inside the cervix, showing the need for training. Recently, Fernandes Jr. (2001) observed that skills $(\mathrm{P}<0.01)$, insemination courses $(\mathrm{P}<0.05)$ and recycling $(\mathrm{P}<0.01)$, generated significant differences in the pregnancy rates obtained by inseminators at the first insemination.

The pregnancy rate also varied among the satisfied inseminators (36.5\%) and dissatisfied inseminators (32.3\%) with their wages ( $\mathrm{P}=0.0419 ; \chi^{2}=9.61$ ), but it was not different among those who had future plans, whether individual or collective (38.4\% and $37.1 \%$, respectively; $\left.\mathrm{P}=0.0711, \chi^{2}=5.29\right)$. These results confirm the findings by Barbutto Jr. et al. (2004) in which the main source of motivation among American rural workers was what the authors called self-concept, that is, these professionals would be more motivated by procedures that reinforced their personal competence standards, enabling selfrealization in the work. Similar findings were reported by Tang (2007), who suggested that quality of life was more related to satisfaction with the work itself than with the wages and that the workers needed something in addition to better salaries for them being effectively motivated.

Thus, meeting the basic needs was an important factor in determining the performance of the inseminator and this corroborates with the theories proposed by Maslow \& Herzberg that motivation occurs from deficiency, or rather, because of it, man searches to complete that which he is lacking (Hagerty, 1999). However, according to these theories, satisfaction of the primary needs (biological, personal safety and financial) would only prevent dissatisfaction at work while the other needs, especially that of self-realization, would effectively be responsible for the motivation and would have a much more significant and stable effect on the productivity of the workers (Chiavenato, 1999). However, this will only happen when the low levels of needs are properly met. 
It is also pointed out that the mentioned theories were developed from studies on urban workers, whose reality is quite different from that lived by rural workers. In the city, the work environment is almost always separate from the place of housing and leave is guaranteed at least one day a week. Furthermore, there are many leisure activities available, the wages are normally incremented with benefits and there are many offers of professional qualification courses. In the country, the routine is very different: the farm is the place of residence and also the work environment. The neighbors are the work colleagues and leisure installations, when they exist, are precarious and contribute little to improving social interaction. Furthermore, training courses are rare and salaries are not always readjusted, which can diminish purchasing power.

Considering these aspects, some reflections are necessary: up to what point could Maslow's theory be applied to rural workers? Are the needs of the rural worker the same as those of the urban worker? Would the needs pyramid be the same?

Although the results of this study do not fully answer all these questions, there may be differences. The principal component graph (Figure 2) proves that, although the satisfaction of the financial need has been related to the pregnancy rate, and, therefore to the result of the inseminator, this association was more distant than that found for the satisfaction of biological needs, for example, that might suggest that under these conditions the financial question would have less weight in determining the results of the professionals.

This conclusion can be easily understood if the differences are considered in the personal expenses of rural and urban workers. Perhaps because of these differences in needs and expenses, housing conditions and interpersonal relationships in the rural area are more important than wages. Furthermore, if the motivation is strongly propelled by meeting the needs of self-esteem and self-realization, it is easy for these needs to be very little met in most rural companies, bearing in mind that few training courses are offered and there are almost no career plans for the workers.

\section{Conclusions}

The level of satisfaction of individual needs interferes in the results obtained in the artificial insemination programs, therefore, factors linked to personal life and work may be important in the performance of the inseminator. Although it has been associated to pregnancy rate and the results obtained by inseminators, financial remuneration seems to have less weight than housing quality and interpersonal relationships in determining these results.

\section{Acknowledgments}

The authors thank FUNDECT-MS for financial support; CAPES for the MSC grant, Professor Diva Lopes da Silveira for helping in the elaboration the questionnaires, Professor Ivan Barbosa Machado Sampaio for collaborating in the statistical analyses, and the farms for supplying the other information necessary for the research.

\section{References}

BARBUTTO JR., J.E.; TROUT, S.K.; BROWN, L.L. Identifying sources of motivation of adult rural workers. Journal of Agricultural Education, v.45, n.3, p.11-21, 2004.

CHIAVENATO, I. Introdução à teoria geral da administração. 5.ed. Rio de Janeiro: Campus, 1999. 920p.

DE MASI, D. O ócio criativo. Entrevista a Maria Selena Palieri (Tradução de Lea Manzi). Rio de Janeiro: Sextante, 2000. 336p.

FARAGHER, E.B.; CASS, M.; COOPER, C.L. The relationship between job satisfaction and health: a meta-analysis. Occupational and Environmental Medicine, v.62, p.105-112, 2005.

FERNANDES JR., J.A. Inseminação artificial em gado de corte: impacto da equipe de inseminadores nos resultados obtidos. 2001. 87f. Dissertação (Mestrado em Medicina Veterinária) - Faculdade de Ciências Agrárias e Veterinárias/ Universidade Estadual Paulista, Jaboticabal.

HAGERTY, M.R. Testing Maslow's hierarchy of needs: national quality of life across time. Social Indicators Research, v.46, p.249-271, 1999.

INSTITUTO NACIONAL DE PESQUISAS ESPACIAIS - INPE [2008]. Disponível em: <http://www.inpe.br>. Acesso em: 15/01/2008.

KING, G.J.; MACPHERSON, J.W. Observations on retraining of artificial insemination technicians and its importance in maintaining efficiency. Canadian Veterinary Journal, v.6, p.83-87, 1965

MICHIE, S. Causes and management of stress at work. Occupational and Environmental Medicine, v.59, p.67-72, 2002.

MOITA NETO, J.M.; MOITA, G.C. Uma introdução à análise exploratória de dados multivariados. Química Nova, v.21, n.4, p.467-469, 1998.

PETERS, J.L.; SENGER, P.L.; ROSENBERGER, J.L. et al. Radiographic evaluation of bovine artificial inseminating technique among professional and herdsman-inseminators using .5 and .25-ml french straws. Journal of Animal Science, v.59, n.6, p.1671-1683, 1984.

PFEIFER, L.F.M.; CASTILHO, E.M.; ROLL, V.F.B. et al. Efeito da duração do tratamento com progestágeno e da maturidade sexual na taxa de prenhez em novilhas de corte: avaliação econômica e biológica. Revista Brasileira de Zootecnia, v.38, n.7, p.1205-1210, 2009

REURINK, A.; DEN DAAS, J.H.G.; WILMINK J.B.M. Effects of AI sires and technicians on non-return rates in the Netherlands. Livestock Production Science, v.26, n.2, p.107-118, 1990.

STATISTICAL ANALYSIS SYSTEM - SAS. User's guide: Stat version 8. Cary: SAS Institute Inc., 1999. 3809p.

TANG, T.L. Income and quality of life: does the love of money make a difference? Journal of Business Ethics, v.72, p.375-393, 2007. 
TEIXEIRA, M.L.; FREITAS, R.M.V. Acidentes do trabalho rural no interior paulista. São Paulo em perspectiva, v.17, n.2. p.81-90, 2003.

TERTULIANO, K.L. Fatores externos que afetam a produtividade humana em seu ambiente de trabalho. 2003. 156f. Dissertação (Mestrado em Engenharia de Produção) Universidade Federal de Santa Catarina, Florianópolis.

VENDRUSCOLO, M.; KOZICKI, L.E.; SEGUI, M.S. et al. Relação entre a duração do ato da inseminação artificial em bovinos e a fertilidade. Archives of Veterinary Science, v.10, p.81-88, 2005. 